\title{
Comment: Government Secrecy and the Constitution
}

\author{
Gerhard Casper $\dagger$
}

The popularity of Professor Sunstein's paper is evidenced by the fact that I am the one who has been selected to respond to it. It is well known that the one thing deans are loath to do is publicly criticize their own faculty. Let me first turn to my agreements with Professor Sunstein and then I will, very timidly, as behooves a dean, venture soine criticisms.

First, I agree that the first amendinent can be understood, as Professor Sunstein suggests, as an organizational, structural provision. ${ }^{1}$ His reformulation of the Meiklejohn approach provides the right focus: one of the functions of the first amendment is to protect against self-interested representatives and the risk of usurpation by government factions-or, put differently, the first amendment helps assure that the einperors' nakedness will be pointed out when they falsely claim to be clothed in the public interest. ${ }^{2}$ This function of the first amendment is of prime importance when we consider government secrecy.

My second agreement with Professor Sunstein has to do with his rejection of what he calls the "equilibrium" theory. ${ }^{3}$ I grant that aesthetics is about all it has going for it.

Now let me turn to my disagreeinents and questions.

First of all, the characterization of Professor Sunstein's own approach as "Jeffersonian," while conceptually acceptable, is historically misleading. To be sure, Jefferson thought it was an "abominable" precedent to conduct the Constitutional Convention in secrecy, yet as president, Jefferson emphatically asserted the authority to claim what has since becoine known as "executive privilege."4

Secondly, even though I accept Professor Sunstein's structural view of the first amendinent and his broad redefinition of the purposes it serves, I still consider its text and history as severely limiting its rele-

$\dagger$ Dean \& William B. Graham Professor of Law, University of Chicago Law School. Referendar 1961, Hamburg; LL.M. 1962, Yale Law School; Dr. iur. utr. 1964, Freiburg i. Br; LL.D. 1982, John Marshall Law School.

1. Sunstein, Government Control of Information, 74 CALIF. L. Rev., 889, 900 (1986).

2. Id. at 892 .

3. Id. at $898-904$.

4. For an account of the position Jefferson took in the treason trial of Aaron Burr, see D. Malone, Jefferson the President-Second Term, 1805-1809, at 320 (1974). 
vance to the matter of government control of information. I am less convinced than Professor Sunstem that the first amendment per se has anything to say about the refusal to disclose information. I would rely more on the constitutional scheme in its entirety to ferret out how government secrecy should be viewed under the Constitution. ${ }^{5}$

One does not, however, have to agree with my views on constitutional interpretation, which are more oriented toward text and history than is fashionable among law professors these days, to accept the proposition that other constitutional provisions are highly relevant.

While Professor Sunstein makes reference to the secrecy of the Constitutional Convention, he fails to note the journal secrecy clause in article I, section 5. That clause provides: "Each house shall keep a Journal of its Proceedings and from time to time publish the same, excepting such Parts as may in their judgment require Secrecy."

There is also the statement and account clause, which says, "[A] regular Stateinent and Account of the Receipts and Expenditures of all public Money shall be published from time to time."7 Although the publication requirement suggests that there should be no secrecy with respect to moneys, the clause allows the government a fair amount of discretion about what accounts to make public and when. ${ }^{8}$

Governmental practice, as early as the first Congresses of the United States, included secret expenditures. ${ }^{9}$ Also, in those early years, presidential communications to the Congress were frequently placed under an injunction of secrecy, which the Congress occasionally assumed it had the power to lift. ${ }^{10}$

Rather than focus solely on the first aniendment, I prefer to look at the Constitution as a whole, as well as at the structure of representative government. The point of the matter is not the need for public deliberation as such, or the need for executive privilege as such, but the need of the United States government (which includes the Congress and the People) for both information and secrecy. What Professor Sunstein treats as government interests are also the interests of the American people. They have a need for secrecy in some circumstances as compelling as their need for information.

5. For an articulation of the structural and relational approach, see C. BLACK, STRUCTURE AND RELATIONSHIP IN CONSTITUTIONAL LAW (1969).

6. U.S. CONST. art. I, $\$ 5$.

7. U.S. ConsT. art. I, $\S 9$.

8. For a detailed review of the matter, see Whether Disclosure of Funds Authorized for Intelligence Activities is in the Public Interest: Hearing before the Select Committee on Intelligence of the United States Senate, 95th Cong., 1st. Sess. 85 (1977) (Prepared statement of Gerhard Casper).

9. See, e.g., Act of July 1, 1790, ch. 22, 1 Stat. 128; Act of Feb. 9, 1793, ch. 4, 1 Stat. 299; Act of March 20, 1794, ch. 7, 1 Stat. 345.

10. See, e.g., 6 ANnals of Cong. 2235 (1797). 
Of course, the matter is not as simple as balancing the interests of one individual against those of another. The relationships are more complex than that. Neither is it simply a case of balancing the interest of one against the interests of the many. Take the example of an mformant who wants to keep his or her identity corifidential. Here, one inust strike a balance between the interests in secrecy and in information. The focus, however, is not so inuch on the informant's personal interest in anonymity as on the interest of the people in assuring the anonymity of informants to facilitate the gathering of information. Similarly, in the case of governmental secrecy, we must consider the people's interest in information and the people's interest in secrecy.

As Professor Sunstein recognizes, representative government to some extent substitutes deliberation by representatives for deliberation by the people. One reason, as illustrated by the journal secrecy clause, is the perceived need for confidentiahty. Freedoin of information cannot be the cure-all. Whether we like it or not, we sometimes inust pass judgnient on our servants in government by evaluating their actions without access to relevant background infornnation. At times we inay even be reduced to nothing but trust in our representatives.

Put differently, the Constitution does not commit the country to the free circulation of information at any price. The Founders understood that unrestrained freedom of mfornation may impose prohibitive social costs.

This leads me to draw specific conclusions with respect to the two specific subject areas covered by Professor Sunstein: the problem of technical data ${ }^{11}$ and the free speech right of government employees. ${ }^{12}$

First, with respect to the problein of technical data, the first question I would ask is whether the country should and may ex ante inpede the flow of techmical data. From this perspective, one would likely take a dim view of curtailing scientific data flows since they are indispensable for further scientific discoveries. On the other hand, less stringent considerations may apply to the trade in mainly cominercially useful data. Again, how little of the former and how much of the latter to impede cannot possibly be decided in the abstract, nor, in my opinion, by the executive branch. The extent to which we impede information flows at all is, in light of the importance of the issue, a matter that calls for a legislative judgment and for wide and open debate which will bring out all the costs associated with such ineasures. I find it rather disconcerting that the executive branch, as it presently does, should take it upon itself to make these decisions.

11. Sunstein, supra note 1 , at $905-12$.

12. Id. at $912-20$. 
Second, with respect to the free speech right of government employees, of course, government employees should not be forced to surrender their constitutional rights. These, however, may be limited by other constitutional concerns. The main issue is whether, all circumstances considered, the electorate would rather forego disclosure by present or former government employees or suffer an increase in its own long-term information costs. I agree with Professor Sunstein that the "waiver of constitutional rights" theory, ${ }^{13}$ the question of who owns the information, ${ }^{14}$ and the economic analysis of the contractual relationship ${ }^{15}$ are all beside the poimt. Froin both an individual rights and a structural perspective of the first ainendment, confidentiality agreements per se are not dispositive. In most instances, there is no way around a case-by-case analysis of the problems, if necessary, in cainera.

\section{CONCLUSION}

While restrictions on the disclosure of confidential information by government employees raise constitutional concerns, an analysis grounded solely im the first annendment cannot be dispositive. Explicit language in the Constitution, reinforced by structural considerations and by persistent government practice, recognizes confidentiality as a legitimate interest.

A broader view of the Constitution and of representative government gives a better perspective on the subject. The people of the United States have interests both in information and in secrecy. In the constitutional balancing of these interests, the first ainendinent plays a significant role, but not necessarily a decisive one.

Similarly, whether and to what extent technical data flows may be limited camiot be resolved in the abstract. These matters must be evaluated in light of their costs, with such evaluation taking place in a legislative proceeding.

Structural reinterpretations of the first amendment such as Professor Sunstein's add to the factors we inust consider in dealing with secrecy issues. However, an analysis of these issues must also assess countervailing structural considerations. "The People," through their constitution and representative government, seek to accomplish a variety of purposes, including necessary and responsible secrecy.

\footnotetext{
13. Id. at 914-16.

14. Id. at 916-18.

15. Id. at $918-20$.
} 